ISSN: 2146-3042

DOI: $10.25095 /$ mufad.510681

\title{
Türk Bankacılık Sektöründeki Faiz Dıșı Gelirlerin Banka Geliri Ve Riski Üzerindeki Etkisinin Ölçülmesi*
}

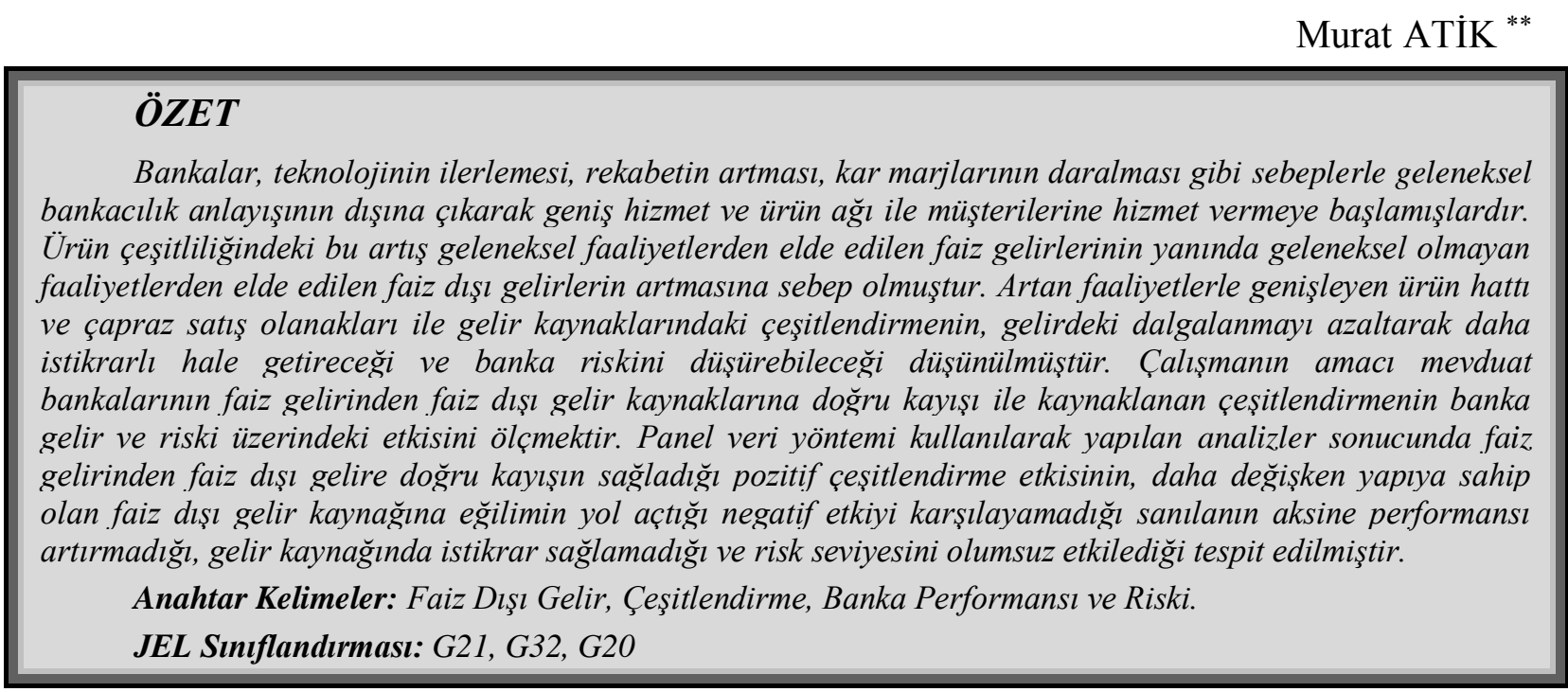

\begin{abstract}
Measurement Of The Effects Of Non Interest Income On Bank Revenues And The Risk In The Turkish Banking Sector

\section{ABSTRACT}

Banks have begun to serve customers with a wide range of services and product network by going beyond the conventional banking concept on account of technological progress, increasing competition, narrowing profit margins. This increase in product diversity has led to an increase in non-interest income from nontraditional activities as well as interest income from traditional activities. It is thought that the diversification of revenue sources with product lines and cross-selling opportunities that are expanding with increasing activity will make the fluctuation of the income more stable and stabilize it and decrease the risk of banking. The purpose of the study is to measure the effect of diversification on the bank's income and risk due to the shift from interest income to non-interest income. As a result of analysis using panel data method, it is seen that positive diversification effect of interest income from interest income to non-interest income does not increase performance, does not stabilize income source and negatively affects risk level.
\end{abstract}

Keywords: Non-Interest Income, Diversification, Bank Performance and Risks.

Jel Classification: G21, G32, G20

\footnotetext{
* Bu çalışma "Bankacılık Sektöründe Faiz Dışı Gelirlerin Banka Geliri Ve Riski Üzerindeki Etkisinin Ölçülmesi: ABD ve Türkiye'deki Lider Bankalar Üzerine Bir Uygulama” adlı doktora tezinden türetilmiştir.

** Dr., Milli Savunma Üniversitesi, matik@kho.edu.tr, ORCID ID: 0000-0002-5150-0203
} 


\section{GİRIşs}

Türk Bankacılık Sektörü 2000'li yıllardan sonra geleneksel bankacılık faaliyetlerinden geleneksel olmayan bankacılık faaliyetlerine doğru büyük bir dönüşüm içine girmiştir. Bankacılık gelirlerinin tek bir kaynağa bağlı olan bir yapıdan çıkması, kaynak içindeki faiz dışı gelir payını artırmıştır.

Bankalar yüksek enflasyonun hâkim olduğu 1980 ile 1999 yılları arasında kaynaklarının büyük bir bölümünü faiz gelirlerinden elde etmiş ve yeni ürün geliştirmek için fazla çaba göstermemişlerdir. Söz konusu dönemlerde bankaların "mevduat topla, devlete borç ver" anlayışı içinde hareket etmeleri gerçek bankacılık faaliyetinden uzak bir anlayış sergilemelerine sebep olmuştur. Bankalar bu dönemlerde hazine kâğıtlarından oluşan varlıklarını daha fazla büyütmek için mevduat toplama yarışına girmişlerdir. Toplanan mevduatın piyasalara kredi olarak kullandırılmasıyla geri dönüşümünün zor olacağı kaygısı, bankaları kredi kullandırmayıp, bunun yerine risksiz ve yüksek faizli Devlet İç Borçlanma Senetlerine (DİBS) yatırım yapmaya yönlendirmiştir.

2000'li yıllardan sonra teknolojinin ilerlemesi, enflasyonun ve faiz oranlarının düşmeye başlaması ve banka kâr marjlarının giderek azalmasıyla, bankalar gelir kayıplarını önlemek için hazine kaynaklı olmayan gerçek bankacılık hizmetlerini sunmaya başlamış ve müşteri odaklı yeni hizmet geliştirme yarışına girmişlerdir. Bankaların geliştirdikleri veya yeni sunmuş oldukları bankacılık hizmetlerinden (havale, eft, çek ve senet, yatırım, krediler, kredi kartı, internet, döviz işlemleri, kasa kiralama, sermaye piyasası ve türev işlemleri vb.) masraf ve hizmet bedeli almaya başlamaları gelir kaynakları içindeki faiz dışı gelir paylarının artmasını sağlamıştır. Alınan hizmet ve masraf bedelleri bankalar için önemli bir rekabet aracı haline gelmiştir. Bankaların konut kredisindeki faiz oranları yaklaşık birbirleri ile aynı düzeyde iken aldıkları komisyon ücretleri ile farklılaşmaları müşteri tarafından tercih edilme sebebini yaratmıştır.

$\mathrm{Bu}$ çalışmada mevduat bankalarının geleneksel bankacılık faaliyetlerinden geleneksel olmayan bankacılık faaliyetlere doğru kaymasının sonucunda artan faiz dışı gelir payının banka kârlarını istikrarlı ve düzenli hale getirip getirmediği, riski azaltarak performansı artırıp artırmadığı incelenmiştir.

\section{LITERATÜR TARAMASI}

Banka gelirlerinin tek bir kaynağa bağlı olmaması durumunda kârlılığ1 arttıracağ1, geliri daha istikrarlı hale getireceği ve banka riskini düşürmeye yardımcı olabileceği öngörülmüştür. Faiz dışı gelire doğru kayışın pozitif etki göstermesi ise aşağıda sıralanan sebeplerle açıklanmaya çalışılmıştır.

-Faiz dışı gelirin büyümesi için sunulan genişletilmiş ürün, hizmet ve çapraz satış imkânları sonucunda bankaların gelir kaynaklarını çeşitlendirebileceği,

-Faiz dışı gelirlerin faiz gelirine oranla iş koşullarından daha bağımsız olabileceği ve kârdaki dönemsel değişkenliği azaltabileceği, 
-Faiz dışı gelir ile faiz geliri arasında negatif bir ilişki oluşturulabilirse banka riskini ve getirisini olumlu etkileyebileceği,

-Faiz dışı gelir ile risk azaltılırsa bankaların sermaye ihtiyacı azalacağı için kaynaklarını farklı yerlere tahsis etmesinin mümkün olabileceği,

-Bankaların faaliyetlerini çeşitlendirmesinin rekabet üstünlüğü sağlayabileceği,

-Bankaların öngörülen risklerindeki düşüşün denetim maliyetlerinde düşmeyi sağlayabileceği ve sonuç olarak faiz dışı gelire doğru kaymanın banka kazançlarını daha kararlı hale getirerek banka riskinin düşmesine yardımcı olabileceği öngörülmüştür (Stiroh, 2002).

Chiorazzo vd. (2008), 1993-2003 yılları arasında İtalyan bankacılık sektöründe faaliyet gösteren bankaların gelir kaynaklarındaki çeşitlilik ve risk-getiri düzeyine yönelik yaptıkları araştırmada banka büyüklüklerine göre az faiz dışı gelire sahip küçük bankaların, faiz dışı gelir paylarındaki artışın performanslarını artırdıklarını bulmuşlardır. Smith vd. (2002) ise 1994-1998 yılları arasındaki 15 ülkenin faiz dışı gelir faaliyetlerini incelemiş ve çeşitlendirmenin riski azaltabilmesi ancak farklı iş kolları ve farklı faaliyetler arasındaki korelasyonun yönüne bağlı olacağını tespit etmiştir.

Tortosa (2003) tarafindan 1986-1997 yılları arasındaki İspanya'daki mevduat bankalarının verileri için dağılım analizine dayalı bir yaklaşım kullanarak geleneksel olmayan faaliyetlerin maliyet etkinliğindeki önemini araştırdıkları çalışmada, oluşturdukları modele göre geleneksel olmayan faaliyetlerin ortalama maliyet etkinliğini artırdığı bulgusuna ulaşmışlardır.

Mercieca vd. (2007) tarafindan 1997 ile 2003 yılları arasındaki 15 ülkeye ait 755 küçük banka verisi kullanılarak faiz dışı gelir faaliyetlerine doğru eğilimin banka performansı üzerindeki etkisi araştırılmış ve küçük bankaların özellikle düşük faiz marjı ve düşük kâr gücü sebebiyle daha fazla kar elde edebilmek ve etkinliklerini artırabilmek için bu alana yönlenmiş oldukları gösterilmiştir. Baele vd. (2007), faiz dış1 gelirlerin faiz geliri sürecinde ortaya çıktığını ve gelir kaynağındaki çeşitlendirmenin genellikle bu şekilde oluştuğu bulgusuna erişmişlerdir.

Demsetz ve Maxwell (2006) tarafindan Barbados'ta bulunan ticaret bankalarının 1985-2001 yıllarına ait verileri kullanılarak yapılan çalışmada, faiz dışı gelirlerin bankanın dış çevresinden etkilenmediğini ve gelir kaynağ 1 içindeki faiz dışı gelir payına doğru eğilimin banka performansını açıklamada önemli bir rolü olmadığını bulmuşlardır. Çalışmanın bulguları DeYoung ve Rice (2004)'ın bulgularının tersi niteliğindedir.

Stiroh ve Rumble (2006), 1800 finansal şirket üzerine yapıkları araştırmada yeni faaliyetlere fazla bağımlı olma ve dolaylı çeşitlendirme etkisine sebep olan stratejik değişimlerin etkisinin ayrıştırılması için yeni bir öneri sunmuştur. Rogers ve Sinkey (1999), ABD'deki ticari bankalar üzerine yaptıkları çalışmada geleneksel olmayan bankacılık faaliyetlerinin genellikle büyük bankalar tarafından yapıldığı ve çeşitlendirmenin banka stratejisinin bir parçası olarak mevduat toplamdaki riski azaltmak için yapıldığını ifade etmiştir. 
Literatürde faiz dışı gelir payının artmasının performansı artıracağına yönelik çalışmalar bulunsa da tam tersi sonuçlara ulaşan çalışmalar da bulunmaktadır. Stiroh (2002) tarafından yapılan çalışmada 1984 ile 2001 yılları arasındaki 14.000 bankanın gelir kaynaklarının çeşitlendirilmesi ile oluşturulmuş gelir portföyü ve riske göre düzeltilmiş getiri arasındaki ilişki incelenmiş ve faiz dışı gelir getirici faaliyetlere doğru eğilimin getirilerdeki dalgalanmayı azalttığ 1 görüşünün yanlış olduğunu bulmuştur. DeYoung ve Roland (2001) ise ABD'deki 472 banka üzerine yaptığı çalışmada kazançtaki değişkenlik ile komisyon temelli işlemlerin yüksek bir ilişkisinin bulunduğunu tespit etmiştir.Lepetit vd. (2008) tarafindan yapılan 1996-2002 yılları arasındaki 734 Avrupa bankası üzerindeki çalışmada gelir kaynakları içindeki faiz dışı gelir payındaki bir birimlik artışın, banka gelirlerindeki değişkenliği artıracağı tespit edilmiştir. Benzer bulgular Demsetz ve Strahan (1997) tarafindan yapılan çalışmada da faiz dışı gelir faaliyetlerin yüksek risk ile bağdaştığ veya komisyon geliri gibi faiz dışı gelir yaratan faaliyetlere ağırlık vermenin iflas riskini artıracağı gösterilmiştir.

Esho vd. (2005), 1993 ile 2001 yılları arasındaki 198 Avustralya Sigorta Birliğinin kredi faiz gelirlerinin azalması sonucu kredi ve mevduat işlemlerinden alınan komisyon ve işlem ücretlerinin toplam faaliyet geliri içindeki payının artmasıyla yapılan çeşitlendirmenin, bankacılık riskinin artmasına sebep olduğunu tespit etmişlerdir.

Inaba ve Hattori (2007), 70 Japon ticari bankanın komisyon ve işlem tabanlı faaliyetlerinin karlılıkta yaratacağı değişkenlik ve banka istikrarına etkilerini incelemiş ve sonuç olarak faiz gelirleri ile komisyon temelli işlemlerden elde edilen gelirler arasında pozitif bir ilişki olduğunu ve bu ilişkinin ROA'daki değişkenliği artırdığını ancak yönetimin istikrarını etkilemediğini göstermiştir.

Acharya vd. (2006), 106 İtalyan bankası üzerine yaptıkları çalışmada benzer şekilde kredi çeşitlendirmesinin riski azaltıcı ve performansı artırıcı bir etkisinin olmadığı, risk seviyesi yüksek olan bankalar için verimsiz bir denge yarattığını bulmuşlardır. Stiroh (2006), ABD sermaye piyasasında faaliyet gösteren bankalar üzerine yaptı̆̆ 1 çalışmada bankaların faiz dışı gelire ağırlık vermelerinin ortalama sermaye getirilerini yükseltmediği gibi getirideki değişkenlik yüzünden bankaların beta değerlerini artırarak daha riskli bir duruma getirdiğini tespit etmiştir.

\section{UYGULAMA}

\subsection{Veri Seti}

Türk bankacılık sektöründeki faiz dışı gelirlerin banka getiri ve riski üzerindeki etkisini ölçmek amacıyla bankaların üçer aylık dönemlerine ait finansal verileri, Türkiye Bankalar Birliği'nin konsolide olmayan ortak veri gönderim tablosundan alınmıştır. Çalışma 2002 yılının dördüncü çeyreğinden 2017 yılının üçüncü çeyreğine kadarki zaman dilimini kapsamaktadır. Başlangıç yılının 2002 yılının son çeyreği olarak seçilmesinin sebebi 1994, 1999, 2001 yıllarında yaşanan ekonomik krizlerin etkisinden veriyi kurtarmaktır. Ayrıca 2002 y1lı sonrasındaki finansal verilerin belli standartlara göre düzenleme zorunluluğunun getirilmesi finansal tablolar arasındaki karşılaştırmanın daha sağlıklı yapılabilmesini de sağlamaktadır. 


\subsection{Banka Grup ve Sektör Payları}

30 Eylül 2017 tarihi itibariyle Türkiye'de 3 kamusal sermayeli banka, 9 özel sermayeli banka, 20 yabancı sermayeli banka olmak üzere toplam 32'i mevduat bankası faaliyet göstermektedir. Söz konusu 32 mevduat bankasından bazılarının sektör payının küçük olması, bazı bankaların kuruluş amaçlarının farklı olması ve geçmişe dönük verilerin olmaması sebebiyle analizlerin güvenirliliğini artırabilmek için çalışmaya Tablo 1'de gösterilen toplam 16 mevduat bankası seçilmiş ve tabloda bu bankaların grup ve sektör payları gösterilmiştir. Tablo 1'e göre toplam 32 mevduat bankasının 16's1 Türkiye'deki mevduat bankacılık grubunun aktif büyüklüğüne göre \%91,63'lük kısmını oluşturmaktadır.

Tablo 1. 30.09.2017 Tarihi İtibariyle Çalışmaya Alınan 16 Mevduat Bankasının Grup ve Sektör Payları

\begin{tabular}{lcccccc}
\hline & \multicolumn{3}{c}{ Grup Payları } & \multicolumn{3}{c}{ Sektör Payları } \\
\cline { 2 - 7 } Banka & Toplam & Toplam & Toplam & Toplam & Toplam & Toplam \\
& Aktifler & Krediler & Mevduat & Aktifler & Krediler & Mevduat \\
\hline Mevduat Bankaları & $\mathbf{9 1 , 6 3}$ & $\mathbf{9 1 , 8 0}$ & $\mathbf{9 2 , 0 1}$ & $\mathbf{8 6 , 4 1}$ & $\mathbf{8 5 , 6 0}$ & $\mathbf{9 2 , 0 1}$ \\
Kamusal Sermayeli Bankalar & $\mathbf{3 4 , 1 4}$ & $\mathbf{3 5 , 3 4}$ & $\mathbf{3 5 , 5 5}$ & $\mathbf{3 2 , 2 0}$ & $\mathbf{3 2 , 9 5}$ & $\mathbf{3 5 , 5 5}$ \\
T.C. Ziraat Bankası A.Ş. & 14,91 & 15,25 & 15,30 & 14,06 & 14,22 & 15,30 \\
Türkiye Halk Bankası A.Ş. & 10,22 & 10,57 & 11,36 & 9,63 & 9,85 & 11,36 \\
Türkiye Vakıflar Bankası T.A.O. & 9,01 & 9,52 & 8,90 & 8,50 & 8,88 & 8,90 \\
Özel Sermayeli Bankalar & $\mathbf{3 8 , 5 5}$ & $\mathbf{3 8 , 0 6}$ & $\mathbf{3 7 , 9 1}$ & $\mathbf{3 6 , 3 5}$ & $\mathbf{3 5 , 4 9}$ & $\mathbf{3 7 , 9 1}$ \\
Akbank T.A.Ş. & 10,70 & 9,68 & 10,52 & 10,09 & 9,03 & 10,52 \\
Anadolubank A.Ş. & 0,52 & 0,57 & 0,68 & 0,49 & 0,53 & 0,68 \\
Fibabanka A.Ş. & 0,68 & 0,78 & 0,71 & 0,64 & 0,72 & 0,71 \\
Şekerbank T.A.Ş. & 1,03 & 1,06 & 1,11 & 0,97 & 0,99 & 1,11 \\
Turkish Bank A.Ş. & 0,05 & 0,06 & 0,07 & 0,05 & 0,06 & 0,07 \\
Türk Ekonomi Bankası A.Ş. & 2,96 & 3,31 & 3,18 & 2,79 & 3,09 & 3,18 \\
Türkiye İş Bankası A.Ş. & 12,65 & 12,49 & 11,84 & 11,93 & 11,65 & 11,84 \\
Yapı ve Kredi Bankası A.Ş. & 9,95 & 10,12 & 9,80 & 9,38 & 9,44 & 9,80 \\
Yabancı Sermayeli Bankalaryyyyyyyyyyyyy & $\mathbf{1 8 , 9 4}$ & $\mathbf{1 8 , 4 0}$ & $\mathbf{1 8 , 5 5}$ & $\mathbf{1 7 , 8 6}$ & $\mathbf{1 7 , 1 5}$ & $\mathbf{1 8 , 5 5}$ \\
Alternatifbank A.Ş. & 0,64 & 0,65 & 0,58 & 0,61 & 0,61 & 0,58 \\
Denizbank A.Ş. & 4,21 & 3,95 & 4,57 & 3,97 & 3,68 & 4,57 \\
HSBC Bank A.Ş. & 0,90 & 0,79 & 1,02 & 0,85 & 0,74 & 1,02 \\
ING Bank A.Ş. & 1,83 & 2,01 & 1,58 & 1,73 & 1,87 & 1,58 \\
Türkiye Garanti Bankası A.Ş. & 11,36 & 10,99 & 10,80 & 10,71 & 10,25 & 10,80 \\
\hline
\end{tabular}

Kaynak: www.tbb.gov.tr $(27.03 .2018)$.

\subsection{Mevduat Bankalarının Gelir ve Giderleri}

Mevduat bankalarının faaliyet gelirleri, net faiz geliri ve net faiz dışı gelir olmak üzere iki temel kısımdan oluşmaktadır. Net faiz gelirini oluşturan, faiz gelir ve gider unsurları Tablo 2'de yer almaktadır. Bankaların faiz dışı gelir ve gider kalemleri ise Tablo 3 'te gösterilmiştir. 
Tablo 2. Faiz Gelir ve Gider Unsurlar1

\begin{tabular}{ll}
\hline Faiz Gelirleri & Faiz Giderleri \\
\hline Kredilerden Alınan Faiz Gelirleri & Mevduata Verilen Faizler \\
Zorunlu Karş1ıklardan Alınan Faiz Geliri & Kullanılan Kredilere Verilen Faizler \\
Bankalardan Alınan Faiz Geliri & Para Piyasası İşlemlerine Verilen Faizler \\
Para Piyasası İşlemlerinden Alınan Faiz Geliri & İhraç Edilen Menkul Kıymetlere Verilen Faizler \\
Menkul Değerlerden Alınan Faiz Geliri & Diğer Faiz Giderleri \\
Finansal Kiralama Gelirleri & Fonlara Verilen Faiz Giderleri \\
Diğer Faiz Gelirleri & Finansal Kiralama Giderleri
\end{tabular}

Tablo 3. Faiz Dışı Gelir ve Gider Unsurları

\begin{tabular}{|c|c|c|c|}
\hline $\begin{array}{l}\text { Net Ücret } \quad \text { Ve } \\
\text { Komisyon }\end{array}$ & Net Ticari Kar/Zarar & Temettü Gelirleri & Diğer Faaliyet Gelirleri \\
\hline $\begin{array}{l}\text { - Alınan Ücret ve } \\
\text { Komisyonlar } \\
\text { - Verilen Ücret ve } \\
\text { Komisyonlar }\end{array}$ & $\begin{array}{l}\text { - Sermaye Piyasası } \\
\text { İşlem Karı/Zararı } \\
\text { - Türev Finansal } \\
\text { İşlemlerden Kar/Zarar } \\
\text { - Kambiyo İşlemleri } \\
\text { Kar/Zarar }\end{array}$ & $\begin{array}{l}\text { İştiraklerinden, bağlı } \\
\text { ortaklıklarından } \\
\text { faaliyetleri } \\
\text { sonucunda kârdan, } \\
\text { dağıtılan } \\
\text { temettülerden } \\
\text { oluşmaktadır. }\end{array}$ & $\begin{array}{l}\text { Ücret ve komisyon, ticari } \\
\text { kar/zarar, temettü gelirleri } \\
\text { dışındaki gelirlerden } \\
\text { oluşmaktadır. Örn.: Depo } \\
\text { Giderleri Karşılığı, } \\
\text { Haberleşme Giderleri } \\
\text { Karşılığı, Aktiflerin } \\
\text { Satışından Elde Edilen } \\
\text { Gelirler, vb. }\end{array}$ \\
\hline
\end{tabular}

Net faiz dışı gelir hesaplanırken gelir kalemleri arasında "Diğer Faaliyet Gelirleri" bulunurken, gider kalemleri arasında "Diğer Faaliyet Giderleri" bulunmamaktadır. Diğer faaliyet giderleri (personel giderleri, kıdem tazminatı karşıllı̆̆, maddi duran varlık değer düşüş giderleri, maddi ve maddi olmayan duran varlık amortisman giderleri, bakım ve onarım giderleri, reklam ve ilan giderleri, vb.) sadece faiz dışı gelir elde etmek amacıyla yapılmadıklarından toplam faaliyet geliri bulunurken Diğer Faaliyet Gideri gösterilmemiş̧ir.

\subsection{Değişkenlerin Tanımlanması}

\subsubsection{Bağımsız Değişskenler}

Bankaların gelir kaynaklarının çeşitlendirme derecesini ölçmek için Herfindahl Hirschman Endeksi ${ }^{1}$ kullanılmıştır. Herfindahl Hirschman ile hesaplanan çeşitlendirme değeri (DIV), banka gelirlerinin tek bir kaynaktan gelip gelmediğini ve bankanın yapmış olduğu çeşitlendirme derecesini göstermektedir. Gelir kaynağını çeşitlendirme derecesini tespit etmeden önce DIV'in hesaplanması için öngörülen varsayımların bilinmesi ve doğrulanması gerekmektedir (Chiorazzo, 2008).

- $\quad$ Net Faiz Geliri (NET) $\geq 0$,

\footnotetext{
${ }^{1}$ Herfindahl Hirsch Endeksi, temel olarak piyasadaki her bir firmanın pazar paylarının karelerinin toplamı olarak tanımlanmaktadır. Söz konusu endeks ile firmaların piyasadaki yoğunlaşma derecesinin ölçümü amaçlanmaktadır.
} 
- $\quad$ Faiz Dışı Gelir $(\mathrm{NON}) \geq 0$

- $\quad 0 \leq \mathrm{SH}_{\mathrm{NON}} \leq 1$

- $0 \leq \mathrm{DIV} \leq 0,50$

- $\quad \mathrm{SH}_{\mathrm{NET}}+\mathrm{SH}_{\mathrm{NON}}=1$

$\mathrm{SH}_{\mathrm{NET}}$, faaliyet geliri içinde net faiz gelirinin payını, $\mathrm{SH}_{\mathrm{NON}}$ ise faaliyet geliri içinde faiz dışı gelirin payını göstermektedir.

$$
\begin{aligned}
\mathrm{SH}_{\mathrm{NET}} & =\frac{\mathrm{NET}}{\mathrm{NET}+\mathrm{NON}} \\
\mathrm{SH}_{\mathrm{NON}} & =\frac{\mathrm{NON}}{\mathrm{NET}+\mathrm{NON}}
\end{aligned}
$$

Gelir kaynaklarının çeşitlendirme derecesini ölçmek için kullanılan DIV ölçeği faaliyet gelirlerini, net faiz geliri (NET) ve net faiz dışı gelir (NON) olmak üzere iki ayrı kısımda göstermektedir.

$$
\mathrm{DIV}=1-\left(\mathrm{SH}_{\mathrm{NET}}^{2}+\mathrm{SH}_{1}^{2}\right.
$$

DIV sonucunda çıkabilecek en düşük değer 0 ve en yüksek değer 0,50 'dir. DIV değerinin 0,50 çıkması net faiz geliri ile faiz dışı gelir kaynaklarının oranlarının eşit olduğu (tam çeşitlendirme), 0 çıkması ise bankanın tüm gelirlerinin tek bir kaynaktan geldiği (tam yoğunlaşma) anlamına gelmektedir.

Akbank'ın 2010 y1lı ikinci çeyrek döneminde net faiz geliri 2439 milyon TL, net faiz dışı geliri ise 1283 milyon TL'dir. Buna göre faaliyet geliri 3383 milyon TL olmaktadır.

$$
\begin{aligned}
& \mathrm{SH}_{\mathrm{NET}}=\frac{\mathrm{NET}}{\mathrm{NET}+\mathrm{NON}}=\frac{2439}{3722}=0,66 \\
& \mathrm{SH}_{\mathrm{NON}}=\frac{\mathrm{NON}}{\mathrm{NET}+\mathrm{NON}}=\frac{1283}{3722}=0,34 \\
& \mathrm{DIV}=1-\left(\mathrm{SH}_{\mathrm{NET}}^{2}+\mathrm{SH}_{\mathrm{NON}}^{2}\right)=1-\left(0,66^{2}+0,34^{2}\right)=0,45
\end{aligned}
$$

Akbank'ın gelirlerinin \%66'sı faiz gelirlerinden, \%34'ü ise faiz dışı gelirlerden oluşmakta ve gelirleri tek bir kaynağa bağlı değildir. DIV değerinin 0,45 gibi 0,50'ye yakın bir değer çıkması, Akbank'ın söz konusu dönem için gelir kaynaklarını çeşitlendirdiğini göstermektedir. Herfindahl Hirschman Endeksinin kullanılabilmesi için faiz geliri (NET) ve faiz dışı gelirlerin (NON) pozitif olması gerekmektedir. Bu iki gelir kaynağından birisinin negatif olması DIV ölçeğini anlamsızlaştırmaktadır. 
İngbank'ın 2010 y1lı üçüncü çeyrek döneminde net faiz geliri 800 milyon TL iken net faiz dışı geliri -30 milyon TL olarak gerçekleşmiştir. Buna göre faaliyet geliri 770 milyon TL olmaktadir.

$$
\begin{aligned}
& \mathrm{SH}_{\mathrm{NET}}=\frac{\mathrm{NET}}{\mathrm{NET}+\mathrm{NON}}=\frac{800}{770}=1,03 \\
& \mathrm{SH}_{\mathrm{NON}}=\frac{\mathrm{NON}}{\mathrm{NET}+\mathrm{NON}}=\frac{-30}{770}=-0,03 \\
& \mathrm{DIV}=1-\left(\mathrm{SH}_{\mathrm{NET}}^{2}+\mathrm{SH}_{\mathrm{NON}}^{2}\right)=1-\left(1,03^{2}+\left(-0,03^{2}\right)\right)=-0,06
\end{aligned}
$$

İngbank'ın toplam faaliyet gelirlerinin \%103'ü faiz gelirlerinden oluşurken faiz diş1 giderler -\%3 ile gelirlerini düşürmektedir. DIV değeri ise $-0,06$ olarak hesaplanmaktadır. DIV ölçeğinin varsayımlarından olan NET ve NON değerlerinin pozitif olmasının sebebi DIV'in pozitif değer çıkması sağlamak içindir. Ancak bu durumda bu tür verilerin veri setinden atılması hem veri kaybına hem de çeşitlendirmenin olumsuz etkisinin analizde gösterilmemesine yol açacaktır. $\mathrm{Bu}$ sorunu gidermek için Herfindahl yaklaşımının varsayımında aşağıdaki değişikliklere gidilmiştir.

$$
\begin{aligned}
& \left|\mathrm{SH}_{\mathrm{NET}}\right|+\left|\mathrm{SH}_{\mathrm{NON}}\right|=1 \\
& 0 \leq \mathrm{DIV} \leq 0,50 \\
& \mathrm{SH}_{\mathrm{NET}}=\frac{\mathrm{NET}}{|\mathrm{NET}|+|\mathrm{NON}|} \\
& \mathrm{SH}_{\mathrm{NON}}=\frac{\mathrm{NON}}{|\mathrm{NET}|+|\mathrm{NON}|}
\end{aligned}
$$

Herfindahl Endeksi'ne getirilen bu yeni yaklaşımda toplam değişim miktarı ölçülmeye çalışılmaktadır. Toplam değişimin yüzde kaçının faiz değişkeninden, yüzde kaçının faiz dışı değişkenden kaynaklandığı araştırılmaktadır. Böylece toplam faaliyeti oluşturan parçaların hangisinin negatif bir etki yarattığı da görülebilecek ve kurulacak modele faiz dişı gelir payının etkisi daha doğru yansıtılabilecektir. DIV değişkeni sadece bankanın çeşitlendirme bilgisini sunmakta, çeşitlendirmenin hangi gelir kaynağından yapıldı̆̆ göstermemektedir.

Tablo 4'te iki bankanın NET ve NON sonucunda hesaplanan DIV değeri gösterilmektedir. Tablo 4'e göre her iki bankanın DIV değeri aynı olmasına rağmen iki bankanın da çeşitlendirme stratejileri birbirlerinden tamamen farklıdır. A bankası toplam gelir içindeki faiz dışı gelir payını azaltan bir çeşitlendirme stratejisini planlamışken, B bankası ise tam tersi toplam gelir içindeki faiz dışı gelir payını daha fazla artıran bir çeşitlendirme stratejisini benimsemiştir. 
Tablo 4. Çeşitlendirme Derecesi (DIV)

\begin{tabular}{lllll}
\hline Banka Adı & Faiz Geliri & $\begin{array}{l}\text { Faiz Dışı } \\
\text { Gelir }\end{array}$ & DIV & SH $_{\text {NON }}$ \\
\hline A Bankası & 65TL & $35 T L$ & $\mathbf{0 , 4 5}$ & 0,35 \\
B Bankası & $35 T L$ & 65TL & $\mathbf{0 , 4 5}$ & 0,65 \\
\hline
\end{tabular}

$\mathrm{Bu}$ durumu kontrol etmek ve çalışmanın amacı olan faiz dışı gelirin etkisini ortaya koyabilmek için $\mathrm{SH}_{\mathrm{NON}}$ değişkeninin bağımsız değişken olarak modele eklenmesi gerekmektedir.

\subsubsection{Kontrol Değişkenleri}

Banka gelir kaynaklarının çeşitlendirilmesinin performansları üzerindeki etkisini ölçmek için Tablo 5'teki kontrol değişkenleri kullanılmıştır. Söz konusu kontrol değişkenlerin seçimi aşamasında bağımlı değişkenlerle yüksek ve anlamlı korelasyon içinde olan açıklama gücü yüksek değişkenler geri dönük seçim yöntemine göre belirlenmiştir.

Tablo 5. Kontrol Değişkenleri

\begin{tabular}{|c|c|c|}
\hline S.Nu. & Değişkenin Kısaltması & Açıklama \\
\hline 1 & Kre.Diğ.Al.Krş./Top.Var & $\begin{array}{l}\text { Toplam varlık başına düşen kredi ve diğer } \\
\begin{array}{l}\text { alacaklar değer düşüklüğ } \ddot{u} \text { karşılığını } \\
\text { göstermektedir. }\end{array}\end{array}$ \\
\hline 2 & Faiz Dış1 Gel./Top.Var. & $\begin{array}{l}\text { Toplam varlık başına düşen faiz dışı geliri } \\
\text { göstermektedir. }\end{array}$ \\
\hline 3 & Diğ.Faal.Gid./Top.Var. & $\begin{array}{l}\text { Toplam varlık başına diğer faaliyet giderlerinin } \\
\text { payını göstermektedir. }\end{array}$ \\
\hline 4 & Net Finansal Varlık/Top.Var. & $\begin{array}{l}\text { Toplam varlık içindeki net finansal varlığ } 1 \\
\text { göstermektedir. }\end{array}$ \\
\hline 5 & Diğ.Faal.Gid./Top.Faaliyet Geliri. & $\begin{array}{l}\text { Faaliyet geliri başına düşen diğer faaliyet } \\
\text { giderlerinin payını göstermektedir. }\end{array}$ \\
\hline
\end{tabular}

\subsubsection{Bağımlı Değişkenler}

Bağımsız ve kontrol değişkenleri ile kurulacak modelin Tablo 6'de sunulan bağımlı değişkenler üzerindeki etkisi araştırılmıştır. Tablo 6'da seçilen 6 bağımlı değişkenin kısaltma ve açıklamaları gösterilmektedir. 
Tablo 6. Bağımlı Değişkenler

\begin{tabular}{lll}
\hline S.Nu. & Değişkenin Kısaltması & Açıklama \\
\hline 1 & NIM & Net Faiz Geliri /Top.Varlık \\
2 & ROE & Net Kar / Özsermaye \\
3 & ROA & Net Kar / Top.Varlık \\
4 & RAR $_{\text {ROE }}$ & $\frac{\overline{\mathrm{ROE}}}{\sigma_{\mathrm{ROE}}}$ \\
5 & RAR $_{\mathrm{ROA}}$ & $\frac{\overline{\mathrm{ROA}}}{\sigma_{\mathrm{ROA}}}$ \\
& & $\frac{\overline{\mathrm{ROA}}+\ddot{O ̈ z s e r m a y e / A k t i f ~}}{\sigma_{\mathrm{ROA}}}$ \\
\hline
\end{tabular}

\subsection{Analiz}

Türkiye faaliyet gösteren mevduat bankaların faiz gelirinden faiz dışı gelire doğru eğiliminin etkisini ölçmek için kullanılan değişkenlerin analizi, varsayımların sınanması, analiz yöntemleri ve sonuçları aşağıda incelenmiştir.

\subsection{1.Özet İstatistik}

Türkiye'deki 16 mevduat bankasının 2002 yılı dördüncü çeyrek döneminden 2017 y1lı üçüncü çeyrek dönemine ait özet istatistiki bilgileri Tablo 7'dedir.

Tablo 7. Türkiye'deki Mevduat Bankaları İçin Özet İstatistik

\begin{tabular}{lccccc}
\hline Değişkenler & $\begin{array}{c}\text { Örneklem } \\
\text { Sayısı }\end{array}$ & Ortalama & $\begin{array}{c}\text { Std. } \\
\text { Sapma }\end{array}$ & Min & Maks. \\
\hline SH $_{\text {NON }}$ & 960 & 0,3005 & 0,1506 & $-0,2752$ & 0,9878 \\
DIV & 960 & 0,3842 & 0,0995 & 0,0096 & 0,5000 \\
Diğ.Faal.Gid./Top.Var. & 960 & 0,0226 & 0,0206 & 0,0039 & 0,2739 \\
Kre.Dĭğ.Al.Krş./Top.Var & 960 & 0,0068 & 0,0064 & 0,0000 & 0,0662 \\
Faiz Dişı Gel./Top.Var & 960 & 0,0132 & 0,0131 & $-0,0158$ & 0,1507 \\
Net Fin.Var./Top.Var & 960 & 0,2261 & 0,1413 & 0,0112 & 0,7738 \\
Diğ.Faal.Gid./Top.Faal. Gel. & 960 & 0,5625 & 0,4286 & 0,1753 & 9,7933 \\
\hline
\end{tabular}

Söz konusu dönemde bankaların faiz dışı gelir paylarının $\left(\mathrm{SH}_{\mathrm{NON}}\right)$ ortalaması 0.30, gelir kaynaklarını çeşitlendirme derecesi (DIV) ise 0,38'dir. DIV değişkeninin alabileceği en yüksek değer olan 0,50'ye göre mukayese yapıldığında, bankaların gelir kaynaklarını çeşitlendirdiği ve gelir kaynaklarının tek bir kaynağa bağlı olmadığı görülmektedir. Ancak faiz dışı gelir payının ( $\mathrm{SH}_{\mathrm{NON}}$ ) standart sapmasının 0,15 gibi yüksek değere sahip oluşu faiz dışı payın değişken bir yapıya sahip olduğunu göstermektedir. Asıl faaliyeti faiz geliri olan bankaların faiz dışı paylarının yüksek olması gelecekte bankacılık sektörü için muhtemel bir problemin habercisi olabilecektir. Bu yüzden faiz dışı payındaki dalgalanmaların etkisinin ortaya konması bu açıdan önemlidir. 
Şekil 1. Türkiye'deki Mevduat Bankaların Çeşitlendirme Derecesi

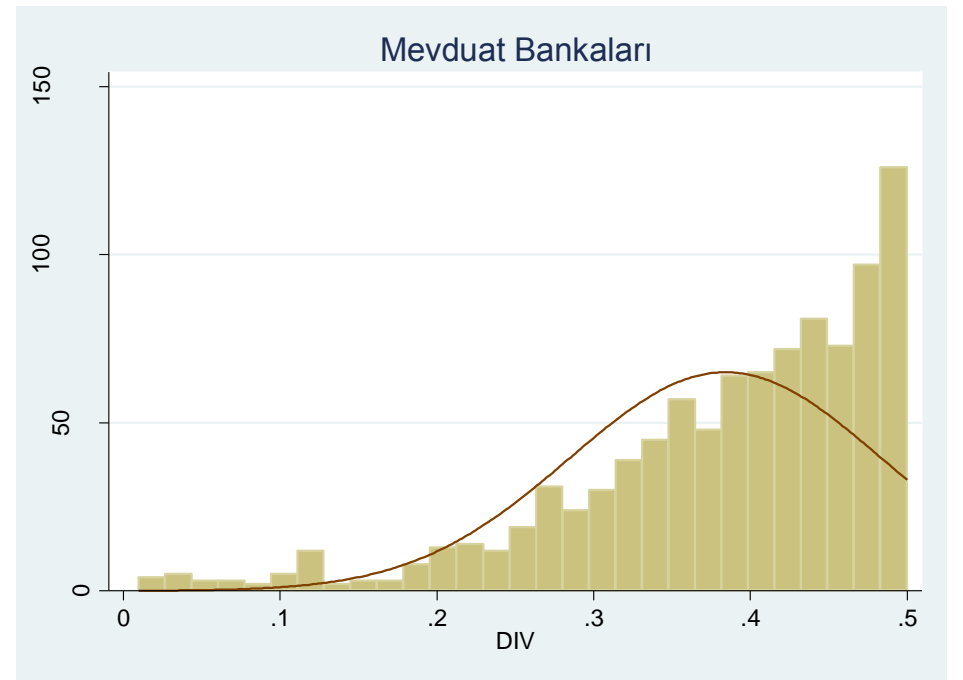

Şekil 1'de mevduat bankalarına ait DIV değişkeninin sıklığı gösterilmektedir. DIV değişkeni 0,50'ye yaklaştıkça net faiz geliri ile faiz dışı gelir arasında eşit bir ayrıma (tam çeşitlendirme) yaklaşılmaktadır. Şekil 1'e göre DIV değişkeninin ortalaması 0,38 ve standart sapması 0,09 olması mevduat bankaları tarafindan faiz dışı gelire doğru bir çeşitlendirme yapıldığını göstermektedir. $\mathrm{Bu}$ durum banka türlerine göre bakıldığında en fazla çeşitlendirmenin 0,39 ortalama ile özel bankalarda, en az çeşitlendirmenin ise 0,37 ortalama ile kamu bankalarında olduğu bulunmuştur.

\subsubsection{Varsayım ve Yöntem}

Mevduat bankalarının gelir kaynaklarını çeşitlendirmesinin performans ve riskleri üzerindeki etkisini tahmin etmek için panel veri analiz yöntemi kullanılmıştır. Panel veri analiz yöntemini kullanabilmek için bazı varsayımlarının sınanması gerekmektedir.

I.Aşama: Çoklu Eşdoğrusallık (Multicollinearity)

Modele seçilen değişkenler arasında çoklu eş doğrusallık problemi araştırılmıştır. Çoklu eş doğrusallık, bağımsız değişkenlerin kendi aralarındaki yüksek korelasyonun regresyon modeline aynı bilgi sağlamasının yol açtığı problemdir. Öncelikle bağımsız değişkenler arasındaki korelasyon katsayıları bulunmuştur.

Tablo 8. Bağımsız Değişkenler Arasındaki Korelasyon Düzeyi

\begin{tabular}{llllllll}
\hline & $(1)$ & $(2)$ & $(3)$ & (4) & (5) & (6) & (7) \\
\hline (1) $\mathrm{SH}_{\text {Non }}$ & 1 & & & & & & \\
(2) DIV & 0,55 & 1 & & & & & \\
(3) Diğ.Faal.Gid./Top.Var. & 0,14 & $-0,01$ & 1 & & & & \\
(4) Kre.Diğ.Al.Krş./Top.Var & 0,11 & 0,11 & 0,33 & 1 & & & \\
(5) Faiz Diş1 Gel./Top.Var & 0,65 & 0,28 & 0,52 & 0,39 & 1 & & \\
(6) Net Fin.Var./Top.Var & 0,27 & 0,15 & $-0,01$ & 0,04 & 0,25 & 1 & \\
(7) Diğ.Faal.Gid./Top.Faal. Gel. & 0,05 & $-0,09$ & 0,46 & $-0,05$ & 0,01 & $-0,10$ & 1 \\
\hline
\end{tabular}


Tablo 8'e göre Faiz Dışı Gel./Top.Var ile $\mathrm{SH}_{\mathrm{NON}}$ değişkenleri arasında yüksek düzeyde ilişki bulunmaktadır. Bu gibi çıkan problemleri kontrolü için değişkenler arasındaki Varyans Büyütme Faktörü (VIF) değerine bakılmıştır. Tablo 9'da VIF değerleri gösterilmektedir. Bağımsız değişkenler arasındaki VIF değerinin 10'dan büyük olması değişkenler arasındaki yüksek korelasyon probleminin varlığını işaret etmektedir.

Tablo 9. Çoklu Eşdoğrusallık Değerleri

\begin{tabular}{lll}
\hline Değişkenler & VIF & 1/VIF \\
\hline Faiz Dışı Gel./Top.Var & 3.55 & 0.282019 \\
SH $_{\text {NON }}$ & 2.96 & 0.338101 \\
Diğ.Faal.Gid./Top.Var. & 2.46 & 0.407170 \\
Diğ.Faal.Gid./Top.Faal. Gel. & 1.64 & 0.610051 \\
DIV & 1.54 & 0.648878 \\
Kre.Diğ.Al.Krş./Top.Var & 1.30 & 0.768518 \\
Net Fin.Var./Top.Var & 1.12 & 0.896536 \\
Ort. VIF & 2.08 & \\
\hline
\end{tabular}

Tablo 9'a göre bağımsız değişkenlerin VIF değerinin 10'dan küçük olmas1, değişkenler arasındaki yüksek doğrusal korelasyonun olmadığını göstermektedir.

II.Așama: Kendiyle İlgileşim (Autocorrelation)

Hata terimlerinin diğer hata terimleri ile arasında ilişki olması otokorelasyon problemini doğurmaktadır. Otokorelasyon, parametrelerin tahmin değerlerinin sapmasız oluşunu etkilememekte ancak standart hataları küçülterek $\mathrm{t}$ ve $\mathrm{F}$ testlerinin güvenilirliğini ve katsayıların anlamlılığını bozmaktadır. Modele seçilen değişkenler arasında otokorelasyon probleminin tespiti için Wooldridge testi yapılmış ve sonuçları Tablo 10'da gösterilmiştir.

Tablo 10. Otokorelasyon Test Sonuçları

\begin{tabular}{lllllll}
\hline Açıklama & NIM & ROA & ROE & RAR $_{\text {ROA }}$ & RAR $_{\text {ROE }}$ & Z-Score \\
\hline F( 1 1 15) & 46.602 & 31.884 & 37.658 & 0.010 & 0.070 & 11.804 \\
Prob > F & 0.000 & 0.000 & 0.000 & 0.9225 & 0.7953 & 0.0037 \\
\hline
\end{tabular}

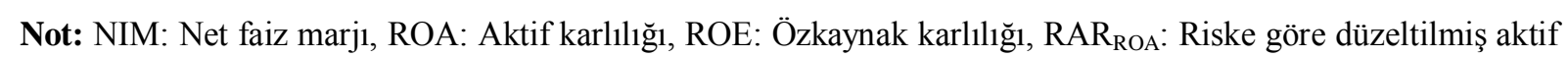
karlılığı, RAR $R_{R O E}$ : Riske göre düzeltilmiş özkaynak karlılığı, Z-Score: Finansal başarısılık riskini göstermektedir.

$\mathbf{H}_{\mathbf{0}}$ : Birinci mertebeden kendiyle ilgileşim yoktur.

Tablo 10'daki sonuçlara göre $\mathrm{H}_{0}$ hipotezi olan "Hata terimleri arasında kendiyle ilgileşim yoktur." hipotezi "Prob > F" değerinin hata payı olarak seçilen katsayıdan yani 0,05 'den küçük olduğu için reddedilmektedir. Wooldridge test sonucuna göre NIM, ROA, ROE ve Z-Score değişkenleri arasında otokorelasyon problemi tespit edilmiştir. 
III.Aşama: Farklı Yayılım (Heteroscedasticity)

Hata terimlerinin farklı yayılıma yani değişen varyansa sahip olması en küçük kareler tekniği sapmasızlık özelliğini korumaya devam ederken, en küçük varyansa sahip olma özelliğini kaybettirmektedir (Güriş ve Çağlayan, 2005).

Tablo 11. Sabit Varyans Test Sonuçları

\begin{tabular}{lllllll} 
Açıklama & NIM & ROA & ROE & RAR $_{\text {ROA }}$ & RAR $_{\text {ROE }}$ & Z-Score \\
\hline chi2(1) & 1055.35 & 754.30 & 3207.66 & 50.12 & 32.70 & 419.45 \\
Prob>chi2 & 0.000 & 0.000 & 0.000 & 0.000 & 0.000 & 0.000 \\
\hline
\end{tabular}

Tablo 11'deki sonuçlara göre $\mathrm{H}_{0}$ hipotezi olan "Hata terimleri sabittir" hipotezi "Prob $>$ chi2" değerinin hata payı değerinden $(0,05)$ küçük olduğu için red edilmektedir. BreuschPagan / Cook-Weisberg test sonucuna göre bütün değişkenlerin hata terimleri arasında değişen varyans problemi tespit edilmiştir.

IV.Aşama: Durağanlılık

Zaman serisinin durağan olması t zamanda varyans ve ortalamanın sabit olması, gecikmeli iki zaman periyodundaki değişkenlerin kovaryansının gecikmeye bağlı olup zamana bağlı olmaması durumudur (Engle ve Granger, 1991:266-267; Gujarati, 2001: 713726). Durağanlık ile zaman serisinin rassal olmaması gerekliliği tespit edilmeye çalışılmaktadır. Tablo 12'deki Levin, Lin, Chu birim kök test sonuçlarına göre değişkenlerin düzeyde durağan I(0) oldukları görülmektedir.

Tablo 12. Levin, Lin, Chu Birim Kök Test Sonuçları

\begin{tabular}{|c|c|c|c|c|}
\hline \multirow[b]{2}{*}{ Değişkenler } & \multicolumn{3}{|c|}{ Model } & \multirow[b]{2}{*}{ Sonuç } \\
\hline & Sabit-Trendli & Sabit & $\begin{array}{l}\text { Sabitsiz- } \\
\text { Trendsiz }\end{array}$ & \\
\hline $\mathrm{SH}_{\mathrm{NON}}$ & $-7.9694 *$ & $-4.0030 *$ & $-6.5566^{*}$ & $\mathrm{I}(0)$ \\
\hline DIV & $-6.9220 *$ & $-2.2478 *$ & $-7.5433 *$ & $\mathrm{I}(0)$ \\
\hline Diğ.Faal.Gid./Top.Var. & $-26.6412 *$ & $-7.6545^{*}$ & -7.5696 & $\mathrm{I}(0)$ \\
\hline Kre.Diğ.Al.Krş./Top.Var & $-14.1721^{*}$ & $-7.8889 *$ & $-8.4560 *$ & $\mathrm{I}(0)$ \\
\hline Faiz Dışı Gel./Top.Var & $-17.0323^{*}$ & -8.3136 & $-7.6769 *$ & $\mathrm{I}(0)$ \\
\hline Net Fin.Var./Top.Var & $-3.6130 *$ & $-6.9709 *$ & $-3.1141 *$ & $\mathrm{I}(0)$ \\
\hline Diğ.Faal.Gid./Top.Faal. Gel. & $-10.8364 *$ & $-3.2989 *$ & $-5.4120 *$ & $\mathrm{I}(0)$ \\
\hline ROA & $-18.2142 *$ & $-7.8824 *$ & $-8.3574 *$ & $\mathrm{I}(0)$ \\
\hline ROE & $-16.8598 *$ & $-7.5837 *$ & $-7.6692 *$ & $\mathrm{I}(0)$ \\
\hline NIM & $-17.6915^{*}$ & $-7.5036^{*}$ & -2.9137 & $\mathrm{I}(0)$ \\
\hline $\mathrm{RAR}_{\mathrm{ROA}}$ & $-5.7126^{*}$ & 0.4145 & $-2.4157 *$ & $\mathrm{I}(0)$ \\
\hline RAR $_{\text {ROE }}$ & $-5.4335^{*}$ & 0.6156 & $-2.6800^{*}$ & $\mathrm{I}(0)$ \\
\hline Z-Score & $-6.4650 *$ & 0.8026 & $-4.0972 *$ & $\mathrm{I}(0)$ \\
\hline
\end{tabular}

Not: *, \%1 seviyesinde anlamlılığı ifade etmektedir. 
Panel veri analizinin gerçek durumu yansıtabilmesi için otokorelasyon ve değişen varyans problemlerini dikkate alan yöntemlerin uygulanması gerekmektedir. Bu problemleri giderebilmek için panel veri analiz yönteminde "Uygulanabilir Genelleştirilmiş En Küçük Kareler Yöntemi” kullanılacaktır. Uygulanabilir genelleştirilmiş en küçük kareler tekniği (Feasible Generalized Least Squares) ile panel veri doğrusal modele uydurulmaya çalışılarak ve panel veri içindeki AR(1) kendiyle ilgileşim ve farklı yayılımın varlığ 1 altında tahmin yapılmıştır.

\subsubsection{Analiz Sonuçları}

Mevduat bankalarının gelir kaynaklarındaki çeşitlendirme ile faiz dışı gelir paylarındaki artışın performansları üzerindeki etkisini gösterebilmek için yapılan panel veri analiz sonuçları Tablo 13 'te gösterilmiştir.

Tablo 13. Panel Veri Analiz Sonuçları

\begin{tabular}{|c|c|c|c|}
\hline Değişkenler & $\begin{array}{l}\text { ROA } \\
\text { (1) }\end{array}$ & $\begin{array}{l}\text { ROE } \\
(2)\end{array}$ & $\begin{array}{l}\text { NIM } \\
\text { (3) }\end{array}$ \\
\hline $\mathrm{SH}_{\mathrm{NON}}$ & $\begin{array}{c}-0.042 * * * \\
(0.003)\end{array}$ & $\begin{array}{c}-0.252^{* * *} \\
(0.023)\end{array}$ & $\begin{array}{c}-0.059 * * * \\
(0.003)\end{array}$ \\
\hline DIV & $\begin{array}{c}0.011 * * * \\
(0.003)\end{array}$ & $\begin{array}{c}0.077 * * * \\
(0.025)\end{array}$ & $\begin{array}{c}0.017^{* * * *} \\
(0.003)\end{array}$ \\
\hline Diğ.Faal.Gid. / Top.Varlık & $\begin{array}{c}-0.284 * * * \\
(0.028)\end{array}$ & $\begin{array}{c}-0.487 * * * \\
(0.187)\end{array}$ & $\begin{array}{c}0.897 * * * \\
(0.034)\end{array}$ \\
\hline Kredi Diğ.Al.Krş. / Top.Varlık & $\begin{array}{c}-0.212 * * * \\
(0.045)\end{array}$ & $\begin{array}{c}-2.121 * * * \\
(0.387)\end{array}$ & $\begin{array}{c}0.432 * * * \\
(0.051)\end{array}$ \\
\hline Faiz Dış1 Gelir / Top.Varlık & $\begin{array}{c}0.962 * * * \\
(0.044)\end{array}$ & $\begin{array}{c}5.328 * * * \\
(0.350)\end{array}$ & $\begin{array}{c}0.123 * * \\
(0.054)\end{array}$ \\
\hline Net Fin.Var./Top.Var & $\begin{array}{c}0.002 \\
(0.002)\end{array}$ & $\begin{array}{c}0.075^{* * * *} \\
(0.017)\end{array}$ & $\begin{array}{c}0.011^{* * * *} \\
(0.002)\end{array}$ \\
\hline Diğ.Faal.Gid./Top.Faal. Gel. & $\begin{array}{c}-0.010 * * * \\
(0.001)\end{array}$ & $\begin{array}{c}-0.086 * * * \\
(0.008)\end{array}$ & $\begin{array}{c}-0.022 * * * * \\
(0.002)\end{array}$ \\
\hline (Constant) & $\begin{array}{c}0.018 * * * \\
(0.001)\end{array}$ & $\begin{array}{c}0.120 * * * \\
(0.010)\end{array}$ & $\begin{array}{c}0.025 * * * \\
(0.001)\end{array}$ \\
\hline Banka Sayıs & 16 & 16 & 16 \\
\hline Gözlem Saylsı & 960 & 960 & 960 \\
\hline Zaman Periyodu & 60 & 60 & 60 \\
\hline
\end{tabular}




$\begin{array}{lccc}\text { Banka Etkisi } & \text { dahil } & \text { dahil } & \text { dahil } \\ \text { Zaman Etkisi } & \text { dahil } & \text { dahil } & \text { dahil } \\ \text { df } & 7 & 7 & 7 \\ \text { chi2 } & 1031 & 694 & 4284\end{array}$

NOT: Parantez içindeki değerler dirençli (robust) standart hatayı göstermektedir. Ki-Kare, 7 serbestlik derecesine göre bulunmuştur. Panel veri içindeki AR(1) kendiyle ilgileşimi, yatay kesit korelasyonunu ve farklı yayılım sorunları dikkate alınarak tahmin yapılmıştır. *, ** ve *** gösterimi sirasıyla $\% 10, \% 5$ ve $\% 1$ istatistiksel anlamll1k düzeyini ifade etmektedir.

Tablo 13'teki performans düzeyini belirlemede kullanılan üç bağımlı değişkenin (ROA, ROE, NIM) sonuçları değerlendirildiğinde DIV değişkenin pozitif çıkması, mevduat bankalarının gelir kaynaklarını çeşitlendirdikçe performanslarının artı̆̆ını göstermektedir. Çeşitlendirme ilkesi gereği gelir kaynağının tek bir kaynağa bağlı olmaması riski azaltıp, getirinin kontrol edilmesini sağlamaktadır. Ancak çeşitlendirmenin bu etkiyi gösterebilmesi için gelir kaynakları arasında negatif ve kuvvetli bir ilişkinin varlığı gerekmektedir. Ekonomik dalgalanma veya kriz ortamlarında faiz gelirinde sorunlar oluşabileceğinden sadece faiz gelirine bağlı bankaların gelirleri olumsuz etkilenebileceklerdir. Oysa faiz gelirlerinden bağımsız faiz dışı gelirlerin ortaya çıkması ile banka gelirleri daha istikrarlı bir hale gelebilecektir.

$\mathrm{SH}_{\mathrm{NON}}$ değişkenin negatif çıkması ise banka gelirlerinin faiz gelirinden faiz dışı gelire doğru kaymasının sonucu faiz dışı paydaki artı̧ıı, banka performansını azalttığını göstermektedir. Gelir kaynaklarının çeşitlendirilmenin (DIV) yarattığ +0.011 pozitif etkiye karşılık, faiz dışı gelir payındaki artı̧s sebebiyle performansı üzerinde -0.042 negatif etkiye yol açmaktadır. Bu durumun sebebi faiz dışı gelirin, faiz gelirine göre daha istikrarsız ve daha değişken bir yapıya sahip olmasından kaynaklanmaktadır.

Faiz dışı gelirin faiz gelirine göre daha düzensiz ve değişken olmasının sebepleri ise aşağıdaki başlıklar altında açıklanabilir;

- Faiz Dışı Gelirin Oluşmasının Faiz Geliri Faaliyetlerine Bağlı Olması: Türk mevduat bankacılığında faiz dışı gelirlerinin büyük bir bölümü faiz geliri yaratan faaliyetler esnasında ortaya çıkmaktadır. Örneğin mevduat bankasının kullandırdığı tüketici kredisi ile faiz geliri doğarken kredi kullandırma esnasında çeşitli isimler altında alınan masraf ve komisyonlar faiz dışı gelirleri oluşturmaktadır. Ancak bu işlemler faiz dışı gelir elde etmek için değil, faiz geliri kazanmak için yapılmaktadır. Dolayısıyla Türkiye'deki mevduat bankalarının faiz dışı gelirleri, faiz geliri faaliyetlerine bağlı olmaktadır. Faiz dışı gelir ile faiz geliri arasındaki korelasyon düzeyinin 0,8774 gibi pozitif ve güçlü bir ilişkinin olması bu hipotezi desteklemektedir. Çeşitlendirmenin temel prensibi aralarında negatif ve güçlü ilişki olan varlıklardan bir portföyün oluşturulmasıdır. Ancak iki gelir kaynağı arasında pozitif yüksek ilişki olduğu sürece bankaların faiz geliri yaratan faaliyetlerden faiz dışı gelir yaratan faaliyetlere doğru kaymalarının çeşitlendirme etkisi ile riski düşürüp performanslarını artırmaları zor gözükmektedir.

- Bankaların Aldıkları Ücretlerden Ötürü Müşterilerin Bankalarını Değiştirebilmeleri: Mevduat bankalarının asıl faaliyet alanı dı̧̧ındaki işlemler için ücret talep etmeleri ve bu işlemler için komisyon, işlem ücretleri vb. istemeleri müşteri kayplarına yol açarak firsat 
maliyeti doğurmakta ve performanslarını olumsuz etkilemektedir. Alınmak istenen masraflar sebebiyle faiz gelirinin kaçırılması fursat maliyetini göstermektedir. Kredi kullandırmak suretiyle düzenli olarak elde edilecek faiz gelirinden vazgeçilerek sadece bir defa mahsus bir gelir kaynağını elde edebilmek için bankanın ısrarcı olması aslında bankalar için büyük bir kayıptır. Faiz gelirinin firsat maliyeti faiz dışı gelir olabilir ancak hiçbir zaman faiz dışı gelirin firsat maliyeti faiz geliri olmamalıdır.

- Düzenli Olmamaları: Faiz dişı gelirlerin genellikle faiz geliri yaratan bir işlem sırasında bir defaya mahsus çıkmaları sebebiyle nakit akışlarını düzenleyici değil, istikrarsız hale getirici etki yaratmaktadır.

- Ortaya Çıkış Zamanının Belirsizliği: Faiz dışı gelirlerin ortaya çıkış zamanı belirsizdir. Örneğin bir müşterinin yaptığ 1 bir EFT işlemi karşılığında alınacak işlem ücretinin ne zaman doğacağı belli değildir. Oysaki faiz geliri yaratan bir faaliyetin ödeme planları önceden belli olduğundan banka nakit akışlarını buna uygun planlayabilmektedir. Ancak faiz dışı gelirin ne zaman doğacağının belirsizliği bu planlamanın yapılmasını engellemektedir. Gelir kaynaklarındaki bu istikrarsız yapı bankanın performansını ve riskini de olumsuz etkileyebilecektir.

Türkiye'de faaliyet gösteren kamusal, özel ve yabancı sermayeli bankalara göre yapılan analiz sonuçları Tablo 14'te sunulmuştur.

Tablo 14. Banka Tiplerine Göre Panel Veri Analiz Sonuçları

\begin{tabular}{|c|c|c|c|c|}
\hline \multicolumn{5}{|c|}{$Y_{i, t}=\alpha_{i}+\beta_{1} \cdot D I V_{i, t}+\beta_{2} \cdot S H_{N O N, i, t}+\gamma \cdot \forall_{i, t}+. \varepsilon_{i, t} \quad \mathrm{i}=1, \ldots \ldots, 16$} \\
\hline \multirow{2}{*}{$\begin{array}{l}\text { Bağımlı Değişken: } \\
\quad R O A\end{array}$} & \multicolumn{4}{|c|}{ Mevduat Bankaları } \\
\hline & $\begin{array}{c}\text { Kamusal } \\
\text { Sermayeli } \\
\text { Bankaları } \\
\text { (1) }\end{array}$ & $\begin{array}{l}\text { Özel Sermayeli } \\
\text { Bankalar } \\
\text { (2) }\end{array}$ & $\begin{array}{c}\text { Yabanc1 Sermayeli } \\
\text { Bankalar } \\
\text { (3) }\end{array}$ & $\begin{array}{c}\text { Bütün Bankalar } \\
\text { (4) }\end{array}$ \\
\hline $\mathrm{SH}_{\mathrm{NON}}$ & $\begin{array}{c}-0.037 * * * \\
(0.006)\end{array}$ & $\begin{array}{c}-0.058 * * * \\
(0.004)\end{array}$ & $\begin{array}{l}-0.008^{*} \\
(0.004)\end{array}$ & $\begin{array}{c}-0.042 * * * \\
(0.003)\end{array}$ \\
\hline DIV & $\begin{array}{c}0.021 * * * \\
(0.006)\end{array}$ & $\begin{array}{c}0.015 * * * \\
(0.005)\end{array}$ & $\begin{array}{c}0.012 * * * \\
(0.004)\end{array}$ & $\begin{array}{c}0.011 * * * \\
(0.003)\end{array}$ \\
\hline Dĭğ.Faal.Gid./ Top.Varlık & $\begin{array}{c}0.616 * * * \\
(0.096)\end{array}$ & $\begin{array}{c}-0.587 * * * \\
(0.029)\end{array}$ & $\begin{array}{c}0.350 * * * \\
(0.038)\end{array}$ & $\begin{array}{c}-0.284 * * * \\
(0.028)\end{array}$ \\
\hline KrediDiğ.Al.Krş./Top.Varlık & $\begin{array}{c}-0.578 * * * \\
(0.089)\end{array}$ & $\begin{array}{c}-0.455^{* * *} \\
(0.067)\end{array}$ & $\begin{array}{l}-0.098 \\
(0.070)\end{array}$ & $\begin{array}{c}-0.212 * * * \\
(0.045)\end{array}$ \\
\hline Faiz Dışı Gelir/ Top.Varlık & $\begin{array}{c}0.550^{* * * *} \\
(0.123)\end{array}$ & $\begin{array}{c}1.428 * * * \\
(0.056)\end{array}$ & $\begin{array}{l}-0.029 \\
(0.050)\end{array}$ & $\begin{array}{c}0.962 * * * \\
(0.044)\end{array}$ \\
\hline Net Fin.Var./Top.Var & $\begin{array}{c}0.001 \\
(0.002)\end{array}$ & $\begin{array}{l}-0.002 \\
(0.004)\end{array}$ & $\begin{array}{c}0.006 \\
(0.006)\end{array}$ & $\begin{array}{c}0.002 \\
(0.002)\end{array}$ \\
\hline
\end{tabular}




$\begin{array}{lcccc}\text { Diğ.Faal.Gid./Top.Faal.Gel. } & -0.021^{* * *} & -0.006^{* * *} & -0.020^{* * *} & -0.010^{* * *} \\ & (0.005) & (0.001) & (0.002) & (0.001) \\ \text { (Constant) } & & & & \\ & 0.012^{* * *} & 0.022^{* * *} & 0.010^{* * *} & 0.018^{* * *} \\ & (0.003) & (0.002) & (0.002) & (0.001) \\ \text { Banka Saylsl } & & & & \\ \text { Gözlem Saylsl } & 3 & 8 & 5 & 16 \\ \text { Zaman Periyodu } & 180 & 480 & 300 & 960 \\ \text { Banka Etkisi } & 60 & 60 & 60 & 60 \\ \text { Zaman Etkisi } & \text { dahil } & \text { dahil } & \text { dahil } & \text { dahil } \\ \text { df } & \text { dahil } & \text { dahil } & \text { dahil } & \text { dahil } \\ \text { chi2 } & 7 & 7 & 7 & 7 \\ & & & & \\ & 2246 & 2153 & 3666 & 1031\end{array}$

Not: Parantez içindeki değerler dirençli (robust) standart hatayı göstermektedir. Ki-Kare, 7 serbestlik derecesine göre bulunmuştur. Panel veri içindeki AR(1) kendiyle ilgileşimi, yatay kesit korelasyonunu ve farklı yayılım sorunları dikkate alınarak tahmin yapılmıştır. ${ }^{*},{ }^{* *}$ ve ${ }^{* * *}$ gösterimi sırasılyla $\% 10, \% 5$ ve $\% 1$ istatistiksel anlamlılık düzeyini ifade etmektedir.

Tablo 14'e göre analiz sonuçları değerlendirildiğinde; çeşitlendirmenin (DIV) performans üzerinde pozitif etki yarattığı ve bu durumun kamu sermayeli bankalarda diğer bankalara göre daha fazla olduğu görülmektedir. Bankalar rekabet üstünlüğü sağlayabilmek için diğer bankalarda olmayan veya fazla çalışmayan hizmetlerini geliştirerek faiz dışı gelirlerini artırmaktadır.

Faiz dışı gelir payının $\left(\mathrm{SH}_{\mathrm{NON}}\right)$ bütün banka tiplerinde göstermiş olduğu etki farklılaşmaktadır. Özellikle özel sermayeli bankalarda gelir kaynaklarını çeşitlendirerek performanslarına sağladıkları 0.015 'lik pozitif etkiye karşılık, kaynaklarını çeşitlendirmek için daha riskli ve istikrarsız bir gelir kaynağı olan faiz dışı gelir paylarını arttırmaları performanslarında -0.058 'luk bir düşüşe sebep olmaktadır. Dolayısıyla bankaların çeşitlendirme uğruna faiz dışı gelir elde etmek için harcadıkları enerji ve zamanı asıl faaliyet konusunu oluşturan faiz geliri elde etmek için harcamaları performanslarına pozitif etki sağlayabilecektir.

Faiz dışı gelir paylarındaki artışın risk üzerindeki etkisini gösterebilmek için yapılan analiz sonuçları ise Tablo 15 'tedir. 
Tablo 15. Panel Veri Analiz Sonuçları

\begin{tabular}{|c|c|c|c|}
\hline Değiş̧ken: & $\begin{array}{c}\mathrm{RAR}_{\mathrm{ROA}} \\
\text { (1) }\end{array}$ & $\begin{array}{c}\mathrm{RAR}_{\mathrm{ROE}} \\
\text { (2) }\end{array}$ & $\begin{array}{c}\text { Z-Score } \\
\text { (3) }\end{array}$ \\
\hline $\mathrm{SH}_{\mathrm{NON}}$ & $\begin{array}{l}1.331 * \\
(0.788)\end{array}$ & $\begin{array}{c}1.529 * * \\
(0.700)\end{array}$ & $\begin{array}{c}-49.079 * * * \\
(-16.892)\end{array}$ \\
\hline DIV & $\begin{array}{c}0.534 \\
(0.502)\end{array}$ & $\begin{array}{c}0.434 \\
(0.444)\end{array}$ & $\begin{array}{c}11.109 \\
(-11.835)\end{array}$ \\
\hline Diğ.Faal.Gid. / Top.Varlık & $\begin{array}{c}11.442 \\
(-9.958)\end{array}$ & $\begin{array}{c}14.972 \\
(-9.413)\end{array}$ & $\begin{array}{c}-1,225.623 * * * \\
(-245.309)\end{array}$ \\
\hline Kredi Diğ.Al.Krş. / Top.Varlık & $\begin{array}{c}1.053 \\
(-6.886)\end{array}$ & $\begin{array}{c}2.119 \\
(-6.649)\end{array}$ & $\begin{array}{c}245.338 \\
(-160.814)\end{array}$ \\
\hline Faiz Dışı Gelir / Top.Varlık & $\begin{array}{l}-20.001 * \\
(-10.512)\end{array}$ & $\begin{array}{c}-22.051 * * \\
(-9.663)\end{array}$ & $\begin{array}{c}552.614 * * * \\
(-208.949)\end{array}$ \\
\hline Net Fin.Var./Top.Var & $\begin{array}{c}-1.285^{* * * *} \\
(0.282)\end{array}$ & $\begin{array}{c}-1.156^{* * *} \\
(0.282)\end{array}$ & $\begin{array}{c}-24.193 * * \\
(-10.555)\end{array}$ \\
\hline Diğ.Faal.Gid./Top.Faal. Gel. & $\begin{array}{c}-2.259 * * * \\
(0.709)\end{array}$ & $\begin{array}{c}-2.349 * * * \\
(0.667)\end{array}$ & $\begin{array}{c}89.696 * * * \\
(-17.012)\end{array}$ \\
\hline (Constant) & $\begin{array}{c}2.896 * * * \\
(0.283)\end{array}$ & $\begin{array}{c}2.838 * * * \\
(0.269)\end{array}$ & $\begin{array}{c}24.695 * * * \\
(-7.256)\end{array}$ \\
\hline Banka Sayısı & 16 & 16 & 16 \\
\hline Gözlem Sayısı & 240 & 240 & 240 \\
\hline Zaman Periyodu & 15 & 15 & 15 \\
\hline Banka Etkisi & dahil & dahil & dahil \\
\hline Zaman Etkisi & dahil & dahil & dahil \\
\hline$d f$ & 7 & 7 & 7 \\
\hline chi2 & 58.37 & 49.13 & 66.05 \\
\hline
\end{tabular}

Not: Parantez içindeki değerler dirençli (robust) standart hatayı göstermektedir. Ki-Kare, 7 serbestlik derecesine göre bulunmuştur. Panel veri içindeki AR(1) kendiyle ilgileşimi, yatay kesit korelasyonunu ve farklı yayılım sorunları dikkate alınarak tahmin yapılmıştır. ${ }^{*}, * *$ ve ${ }^{* * *}$ gösterimi sırasıyla $\% 10, \% 5$ ve $\% 1$ istatistiksel anlamlılık düzeyini ifade etmektedir.

Z-Score faiz dışı gelir payı artıkça düşmektedir. Faiz dışı gelir payındaki bir birimlik artış Z-Score değerini -49.079 birim düşürmektedir. Bu da faiz dışı gelire fazla bağımlı olan bankaların göreceli olarak daha yüksek iflas riskini taşıdıklarını göstermektedir. 


\section{SONUÇ}

Mevduat bankaları gelişen teknoloji, kâr marjlarının azalması, müşterilerin bilinçlenmesi gibi birçok faktör sonucu yeni finansal ürün ve hizmetler geliştirmektedir. Ürün çeşitliliğindeki artışla birlikte geleneksel olmayan gelir kaynaklarındaki artış banka gelirlerinin tek bir kaynağa bağlı olmamalarını sağlamıştır. Gelir kaynaklarındaki bu çeşitlendirme ve faiz gelirinden faiz dışı gelire doğru eğilimin banka performansını artırıp, karlılıktaki dalgalanmayı azaltarak risk seviyesini düşüreceği öngörülmüştür.

Çeşitlendirme ilkesine göre aralarında negatif ve kuvvetli ilişki bulunan finansal varlıklardan oluşmuş bir portföyde riskin azalıp, getirinin kontrol edilmesi mümkündür. Türkiye'deki mevduat bankalarının gelir kaynaklarını çeşitlendirmek için geleneksel faaliyetlerden (faiz geliri), geleneksel olmayan faaliyetlere (faiz dışı gelir) yönelmelerinin banka getiri ve riski üzerindeki etkisi incelendiğinde; gelirin tek bir kaynağa bağlı olmamasının çeşitlendirme etkisi ile performans üzerinde olumlu etki yarattı̆̆ 1 görülmüştür. Ancak Türkiye'deki bankacılık sektöründeki faiz dışı faaliyetler güçlü bir şekilde faiz faaliyetlerine bağımlı olarak gerçekleşmektedir. Bu durum çeşitlendirmenin olumlu etkisini tersine çevirmektedir.

Türkiye'deki bankaların faiz geliri yaratan faaliyetlerden bağımsız olarak faiz dişı faaliyetler yapabilmeleri durumunda nakit akışlarındaki dalgalanma azalarak daha istikrarlı ve kararlı duruma gelebilecektir.

Mevduat bankalarının gelir kaynaklarını çeşitlendirebilmek için faiz gelirinden faiz dışı gelire doğru eğilimleri sonucunda faiz dışı gelir payının artması çeşitlendirmenin yarattığ pozitif etkiden daha fazla negatif etki yaratarak banka performansının azalmasına sebep olmaktadır. Bu durumun asıl sebebi faiz dışı gelirin faiz gelirine göre daha değişken ve istikrarsız bir yapıya sahip olmasıdır.

Faiz dışı gelirin daha değişken bir yapıya sahip olmasının sebepleri ise faiz dışı gelirin doğmasının faiz gelirine bağlı olmasıdır. Türkiye'de faiz dışı gelirler genellikle faiz geliri faaliyetleri esnasında ortaya çıkmaktadır. İki gelir kaynağı arasında 0,8774'lik ilişki bunu göstermektedir. Faiz dişı geliri değişken yapan diğer bir sebep ise ne zaman ortaya çıkacağının belli olmamasıdır. Faiz dışı gelir için yapılan işlemlerin genellikle bir defaya mahsus alınmaları ve bir daha ortaya çıkmaması faiz dışı geliri istikrarsız bir hale getirmektedir. Başka bir sebep ise faiz dışı gelir elde etmek için alınan işlem ve komisyon ücretlerinden ötürü müşterilerin bankalarını değiştirebilmeleridir. Faiz dışı gelir elde etmek için gelir kaynağının istikrarsız bir hale getirilmesi, banka performansını da olumsuz etkilemektedir.

Çeşitlendirmenin avantajı, elde edilen faydanın kayıptan büyük olması durumunda geçerlidir. Ancak araştırma kapsamında elde edilen sonuçlara göre, gelir kaynakları içindeki faiz dışı gelir payının artırılması ile elde edecek fayda, maliyetin altında kalmaktadır. Risk başına düşen getiride ise $\mathrm{SN}_{\mathrm{NON}}$ değişkeni anlamlı olsa da DIV değişkeni istatistiksel olarak anlamlı değildir. Çeşitlendirmenin banka iflas riski üzerine etkisi incelendiğinde faiz dış1 gelire doğru kaymanın iflas riskini artırdığı görülmektedir. 
Sonuç olarak bankacılığın temel fonksiyonu, finansal sistem içinde tasarruf edilen fonları toplayarak fon ihtiyacı olanlara aktarmak ve bu işlem karşılığında faiz geliri elde etmektir. Bankaların, ne zaman ortaya çıkacağı belirsiz ve sürekliliği olmayan bir gelir kaynağına sahip olmak için harcadıkları zaman ve enerjilerini asıl faaliyet alanı olan faiz gelirine yönlendirmeleri durumunda daha sağlam ve istikrarlı bir gelir yapısına kavuşabilecekleri öngörülmektedir. Söz konusu bu durum iki gelir kaynağı arasında negatif ve güçlü bir korelasyon sağlanıncaya kadar devam ettirilmesi gerekmektedir.

\section{KAYNAKLAR}

Acharya, V.Viral - Iftekhar, Hasan- Saunders, Anthony (2006), "Should Banks Be Diversified? Evidence from Individual Bank Loan Portfolios", Journal of Business, Vol. 79, No. 3, pp. 1355-1412.

Baele, Lieven - Jonghe- Olivier De - Vennet, R. Vander (2007), “Does The Stock Market Value Bank Diversification?”, Journal of Banking and Finance, 31(7), pp.1999-2023.

Chiorazzo, Vincenzo - Milani, Carlo - Salvini, Francesca (2008), "Income Diversification and Bank Performance: Evidence from Italian Banks", Journal of Financial Services Research, Vol. 33, Issue 3, pp.181-203.

Craigwell, Roland - Maxwell, Chanelle (2006),"Non-interest Income and Financial Performance at Commercial Banks in Barbados", Savings and Development, Vol. 30, No. 3, pp. 309-328.

Demsetz, S.Rebecca - Strahan, E.Philip (1997), "Diversification, Size and Risk at Bank Holding Companies", Journal of Money, Credit and Banking, Vol. 29, No. 3, pp. 300313.

Deyoung, Robert - Roland, Karin P. (2001), "Product Mix and Earnings Volatility at Commercial Banks: Evidence from a Degree of Total Leverage Model”, Journal of Financial Intermediation, Vol.10, Issue 1, pp. 54-84.

Deyoung, Robert - Tara, Rice (2004), "Noninterest Income and Financial Performance at U.S. Commercial Banks", The Financial Review 39, pp.101-127.

Engle, R. F. - Granger, C.W.J.(1991). "Long-Run Economic Relationships: Readings in Cointegration", Advanced Texts in Econometrics, New York: Oxford University, pp.267-276.

Esho, Neil - Kofman, Paul - Sharpe, Ian G. (2005), "Diversification, Fee Income and Credit Union Risk", Journal of Financial Services Research, Vol. 27, Issue 3, pp. 259-281.

Gujarati, D. N. (2001). “Temel Ekonometri”, Çev: Ümit Şenesen ve Gülay G. Şenesen, Literatür Yayınc1lık, İstanbul.

Güriş, Selahattin - Çağlayan, Ebru (2005), "Ekonometri Temel Kavramlar”, Der Yayınları, İstanbul. 
Inaba, Kei-ichiro - Hattori, Masazumi (2007), “A Contemporary Aspect of Japanese Commercial Banking: Expansion of Fee-Based Business and Its Impact on Management Stability", Bank of Japan Working Paper Series, pp.1-36.

Lepetit, Laetitia - Nys, Emmanuelle - Rous, Philippe - Tarazi, Amine (2008), “The Expansion of Services in European Banking: Implications for Loan Pricing and Interest Margins", Journal of Banking and Finance, 32 (11), pp.2325-2335.

Mercieca, Steve - Schaeck, Klaus - Wolfe, Simon (2007), “Small European Banks: Benefits from Diversification?”, Journal of Banking \& Finance, Vol. 31(7), pp. 1975-1998.

Rogers, Kevin - Sinkey, Joseph F. (1999), “An Analysis of Nontraditional Activities at U.S. Commercial Banks", Review of Financial Economics, Vol., Issue1, pp.25-39.

Stiroh, Kevin J. (2002), "Diversification in Banking Is Noninterest Income the Answer", FRB of New York Staff Report.

Stiroh, Kevin J. - Rumble, Adrienne (2006), "The Dark Side of Diversification: The Case of US Financial Holding Companies”, Journal of Banking \& Finance, 2006, Vol. 30, Issue 8, pp.2131-2161.

Stiroh, Kevin J. (2006), "A Portfolio View of Banking with Interest and Noninterest Activities", Journal of Money, Credit and Banking, Vol. 38, No. 5, pp. 1351-1361.

Tortosa, Emili Ausina (2003), "Nontraditional Activities and Bank Efficiency Revisited: A Distributional Analysis for Spanish Financial Institutions", Journal of Economics and Business, Vol. 55, Issue 4, pp.371-395. 
(81): 271- 292 